\title{
ANALYSIS OF CO-CONTRACTION OF THE TRUNK MUSCLES IN THE SIDE BRIDGE STABILIZATION EXERCISE WITH DIFFERENT UNSTABLE SURFACES
}

\author{
ANÁLISE DA COCONTRAÇÃO DOS MÚSCULOS DO TRONCO NO EXERCÍCIO DE \\ ESTABILIZAÇÃO PRANCHA LATERAL COM DIFERENTES SUPERFÍCIES \\ INSTÁVEIS
}

\author{
Frederico Balbino Lizardo ${ }^{1}$; Michel Alvarenga da Silva ${ }^{1}$; Franciel José Arantes ${ }^{1}$; \\ Fabio Clemente Gregorio ${ }^{1}$; Fhillipe Rodrigues Alves Santos ${ }^{1}$; Felipe Farnesi Ribeiro Borges ${ }^{1}$; \\ Andrei Nakagawa Silva'; Delaine Rodrigues Bigaton ${ }^{3}$ \\ 1. Laboratory of Kinesiologic Electromyography, Federal University of Uberlândia, Brazil. frederico@ufu.br; 2. Laboratory of \\ Biomedical Engineering, Federal University of Uberlandia, Brazil; 3. Postgraduate Program in Human Movement Sciences, \\ Methodist University of Piracicaba, Brazil.
}

\begin{abstract}
The muscle co-contraction is a phenomenon characterized by the simultaneous contraction of two or more muscles around a joint. The objective of this study was to compare the antagonist co-contraction of the local and global trunk muscles during side bridge exercise, in four situations: (a) stable; (b) instability in the upper limbs with bosu; (c) instability in the upper limbs with disc and (d) double instability. The sample consisted of 20 male volunteers and data collection was performed with simple differential surface electrodes. The electromyographic activity was collected from the Rectus Abdominis (RA), Internal Oblique Abdominis (IO), Multifidus (MF) and Erector Spinae (ES). Were utilized specific routines developed in the Matlab program (Mathworks Natick, USA) to calculate the percentage of antagonist cocontraction between local (IO/MF) and global muscles (RA/ES). The collected data were submitted to parametric statistical analysis (repeated measures ANOVA) or non-parametric (Friedman). The results demonstrated that no significant differences were observed in the pattern of global and local co-contraction in the different side bridge exercises with and without unstable surface. It is concluded that the use of unstable surface in the side bridge stabilization exercise does not increase the level of co-contraction of the trunk flexor and extensor muscles compared to normal stability. However, future studies should use a longer time of isometric contraction in trunk stabilization exercises to optimize the understanding of the effects of different unstable equipment on global and local levels of co-contraction of the trunk muscles.
\end{abstract}

KEYWORDS: Electromyography. Core. Bosu. Balance Disk.

\section{INTRODUCTION}

The core is a segment of the body related to the trunk or more specifically to the lumbopelvic region (OLIVER; STONE; PLUMMER, 2010). The core stability is essential to provide a basis for movements of upper and lower limbs in daily activities or sports, withstand loads, prevent disorders as low back pain, develop strength and protect the spinal cord and neural roots (ELLSWORTH, 2012; TAN et al., 2013).

The core muscles are classified as local and global stabilizers accordingly with its functional and anatomic characteristics. The local stabilizers are the deep muscles of the spine (multifidus $[\mathrm{MF}]$ ) and abdominal wall (transversus abdominis [TA] and internal oblique [IO]) and are associated with segmental stability of the spine during body movements or in postural adjustments. The superficial muscles of the abdominal and lumbar regions (rectus abdominis [RA]; external oblique abdominis [EO]; and erector spinae [ES]) are considered global stabilizers that operate in the multi-segmental stability and are agonists in the trunk movements (BEHM et al., 2010; SUNDSTRUP et al., 2012).

With the increasing popularity of core training, different equipment is introduced in the market, among which are unstable surfaces (gymnastic ball, bosu, disk and foam roller) that are widely used in clinical practice and sports (BEHM et al., 2010; SNARR et al., 2016).The unstable surfaces are used in trunk stabilization exercises to increase the overload (CZAPROWSKI et al., 2014, VERA-GARCIA, BARBADO, MOYA, 2014, ATKINS et al., 2015). The logic for using the unstable surface in these exercises is based on the potential to increase trunk disturbance and 
displacement of the center of gravity, requiring greater neuromuscular demand to maintain proper control of the spine during exercise (DESAI, MARSHALL, 2010).

Although recently, Czaprowski et al. (2014) demonstrate greater muscle activity for the RA and EO muscles during the side bridge with unstable surface (bosu) compared to the same exercise in the ground, new equipment and analyzes, such as cocontraction, may contribute to further discussions involving stabilization and motor control patterns during the exercise execution previously mentioned.

The muscular co-contraction is defined by the simultaneous activation of two antagonistic muscle groups to stabilize the joint (MORITA; MARQUES; NAVEGA, 2016) and the cocontraction of the MF and IO muscles is fundamental to increase the stability of the lumbar spine (MARQUES; HALLAL; GONÇALVES, 2012).

Some studies analysed the co-contraction of trunk muscles in different stabilization exercises (MARQUES et al., 2013; ROSSI et al., 2014), However, there are some gaps in the literature about the effects of unstable surfaces in the side bridge, such as: (1) Will double instability (instability in upper and lower limbs) produce greater cocontraction of the trunk muscles compared to simple instability? (2) Will the use of the balance disk produce greater co-contraction compared to bosu? Understanding these questions is fundamental for the optimization of prevention, rehabilitation and sports training programs that aim the development and strengthening of core muscles.

The first hypothesis is that double instability will produce greater trunk disturbance and consequently greater co-contraction compared to the other conditions; the second hypothesis is that the use of the disk will provide a higher co-contraction compared to bosu, due to the lower base of support and ground contact area.

Therefore, the objective of this study is to evaluate the co-contraction of flexor and extensor muscles of the trunk in the side bridge, in four situations: (a) stable; (b) instability on the upper limbs with bosu; (c) instability on the upper limbs with disk and (d) double instability.

\section{MATERIAL AND METHODS}

\section{Design and Participants}

This is an experimental, quantitative and laboratory study, approved by the Etic and Research Committee $\left(\mathrm{n}^{\mathrm{o}}\right.$ 174.012) of Federal University of
Uberlândia (UFU) developed in the Laboratory in Kinesiologic Electromyography.

Was selected a convinience sample composed by 20 male volunteers with a mean age of $23.65 \pm 4.49$ years, body weight $71.31 \pm 7.85 \mathrm{~kg}$, height $175.35 \pm 5.48 \mathrm{~cm}$ and Body Mass Index (BMI) $23.14 \pm 1.74 \mathrm{~kg} / \mathrm{m}^{2}$. As inclusion criteria, all subjects should be considered physically active or very active according to the classification of the International Physical Activity Questionnaire (IPAQ short version), have resistance training experience of at least one year prior to the study and have a normal BMI. The volunteers had no experience in the four side bridge variations, however, all had experience in the side bridge in the ground.

Volunteers with a history of low back pain were excluded, as assessed by the Oswestry Disability Index, and/or any other type of musculoskeletal dysfunction that might interfere with the execution of the exercises. Were also excluded subjects that were using medications that could influence the muscle activity.

The sample size (n) was determined by the sample calculation based on the electromyographic parameter root mean square (RMS) of the RA muscle, obtained in a pilot study with four volunteers. Calculation software was conducted by GPower 3.1, power $80 \%$ and alpha $=0,05$, which provided sample size $n=20$

\section{Electromyographic (EMG) activity}

The EMG activity was performed using a computerized electromyograph MyosystemBr1 P84/DATAHOMINIS Tecnologia Ltda. (Uberlândia, MG, Brazil), which was developed according to standards of the International Society of Electrophysiology and Kinesiology (ISEK), with input impedance of 1015 Ohms, analogic/digital converter with 16-bit resolution, Butterworth filters and integrated rechargeable battery. The EMG signals were collected and later processed using the Myosystem Br1 software (version 3.5.6.). The sampling frequency was $2,000 \mathrm{~Hz}$ per channel throughout the data collection and electromyographic signals were subjected to a $20 \mathrm{~Hz}$ high-pass and $500 \mathrm{~Hz}$ low-pass filters, following the recommendations of SENIAM (Surface Electromyography for the Non-Invasive Assessment of Muscles).

The EMG signals were captured using single differential surface electrodes (DataHominis Tecnologia Ltda.), with a gain of 20 times and rejection reason at common mode of $92 \mathrm{~dB}$ at 60 $\mathrm{Hz}$, composed of two parallel rectangular bars of silver (10 mm long x $1 \mathrm{~mm}$ wide) and spaced 10 
$\mathrm{mm}$ apart. The preparation of volunteers consisted of shaving and cleaning the skin with $70 \%$ alcohol. Surface electrodes were placed on the right antimere muscles (GOTTSCHALL et al., 2013), with parallel orientation and the bars of signal detection perpendicularly to the direction of the muscle fibers (DE LUCA, 1997). Prior to data collection, subjects were asked to identify their preferred hand for writing, which was then considered their dominant arm. All subjects were right-hand dominant (MARCHETTI et al., 2015).

The electrodes were placed in the following locations: (RA) positioned vertically and fixed in the center of the muscular belly at the midpoint between the xiphoid process of the sternum and umbilical scar, approximately 3 centimeters lateral to the median line and 5 centimeters superior to the umbilical scar; (IO) positioned horizontally and placed two centimeters inferomedial to the anterior superior iliac spine (ASIS), within a triangle confined by the inguinal ligament, lateral border of the rectus sheath, and a line connecting each ASIS; (MF) positioned in the level of the spinous process of the fifth lumbar vertebra approximately 2 to 3 centimeters from the median line of the body; (ES) positioned laterally to the spinous process of the third lumbar vertebra approximately 2 to 3 centimeters from the median line (GARCÍAVAQUERO et al., 2012; HERMENS; FRERIKS, 1999; HIBBS et al., 2011).

After placement of the electrodes the volunteers performed specific movements, according to the muscular functions, to verify the correct positioning and examine the quality of the EMG signal (KONRAD, 2005). The reference electrode (Bio-logic Systems - SP Medical, Scientific and Commercial Ltda., São Paulo, SP, Brazil), consisting of a stainless steel disk $(30 \mathrm{~mm}$ diameter x $1.5 \mathrm{~mm}$ thickness), was fixed in the skin on the left iliac crest (HIBBS et al., 2011).

\section{Experimental procedure}

The data collection was divided into two distinct days. In the first, the volunteers were submitted to physical evaluation (stature and body mass), two questionnaires were answered (international physical activity questionnaire: short version - IPAQ and functional evaluation questionnaire: Lumbar Inability Index Oswestry) and performed the familiarization of the exercises. The electromyographic data collection took place a week later, where the volunteers performed all trunk stabilization exercises. The order was random by one draw. Each subject performed two repetitions of each exercise with five seconds of isometric contraction, and a one-minute interval between the repetitions and two minutes between the different exercises was used (EKSTROM; DONATELLI; CARP, 2007).

The stabilization exercises were performed with the normal respiratory rate of each volunteer and are shown in figure 1 . The proprioceptive disk (Disco Flex Multiuso - MERCUR S.A., Santa Cruz do Sul, RS, Brazil) has $30 \mathrm{~cm}$ and was inflated so that the surfaces (both sides of the disk) remain flat, according to the manufacturer's recommendations.

The bosu (BOSU Balance - ISP ELETROMEDICA, Santa Tereza do Oeste, PR, Brazil) supports up to $200 \mathrm{~kg}$, is $55 \mathrm{~cm}$ in diameter and combines a solid base platform with an inflatable blue rubber dome. The bosu was inflated to a recommended height of approximately $25 \mathrm{~cm}$, in which the base platform was resting on the ground and the blue rubber dome facing upwards.

\section{Exercises Executed:}

1-Side bridge: subjects in lateral decubitus with the right arm abducted at $90^{\circ}$, right forearm flexed at $90^{\circ}$, elbow and right forearm resting on the floor. Subjects were instructed to keep the body elevated and aligned in a straight line for 5 seconds using forearm and right foot as support.

2- Instability side bridge: side bridge was performed with simple instability in the upper limbs using the right elbow and forearm supported on the disk or bosu. Double instability was used with bosu and disc.

\section{Data analysis}

EMG signal analysis was carried out using specific routines developed in Matlab (Mathworks_ Natick, USA). The linear envelope EMG data from each muscle, of each participant, was used to calculate the level of co-contraction. For this analysis, the area under the signal amplitude curve was determined for the RA, IO, MF, and ES muscles and the percentage of agonist/antagonist cocontraction (\% COCON) for the local muscles IO/MF and global muscles RA/ES was calculated using the following equation (WINTER, 2005):

$$
\% \text { COCON }=2 \times \frac{\text { commonarea } A \& B}{\text { area } A+\text { area } B} \times 100
$$

Where \% COCON is the percent co-contraction between two antagonist muscles, area $\mathrm{A}$ is the area below the smoothed EMG curve of muscle A, area $\mathrm{B}$ the area below the smoothed EMG curve of muscle $\mathrm{B}$, common area $\mathrm{A} \& \mathrm{~B}$ is the common area of activity of muscles A and B. 

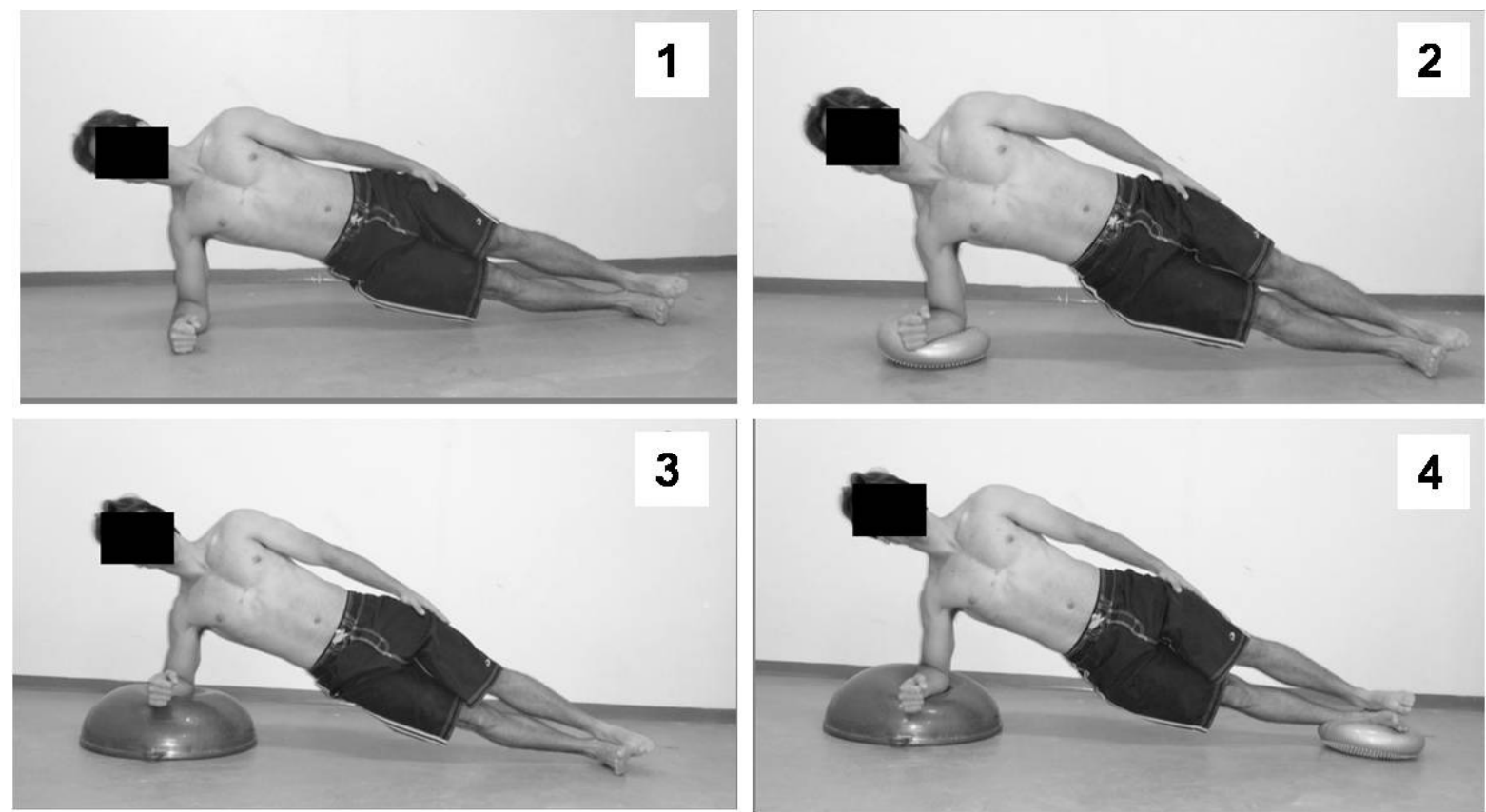

Figure 1. Trunk stabilization exercises: (1) side bridge stable; (2) side bridge with balance disk; (3) side bridge with bosu; (4) side bridge with bosu and balance disk.

\section{Statistical analysis}

The statistical analysis was performed by the SPSS Statistics 2.0 program. KolmogorovSmirnov test was used to evaluate the normality of the data and the Mauchly test to verify sphericity, with Greenhouse-Geisser adjustments, if the sphericity was not assumed. The analysis of variance of repeated measurements (ANOVA) was used to compare the values of global co-contraction between the different exercises, with Bonferroni post hoc. As the local co-contraction data did not present normality, the Friedman non-parametric test was used to compare local co-contraction between the different exercises, in all analyzes the Dunn's multiple comparisons test was performed to verify difference. The level of significance was set at $5 \%$.

\section{RESULTS}

Figures 2 and 3 are showing the cocontraction values between the different side bridge exercises. There were no significant differences $(\mathrm{p}>$ 0.05 ) in the global and local co-contraction pattern in the different side bridge exercises with and without unstable surface.

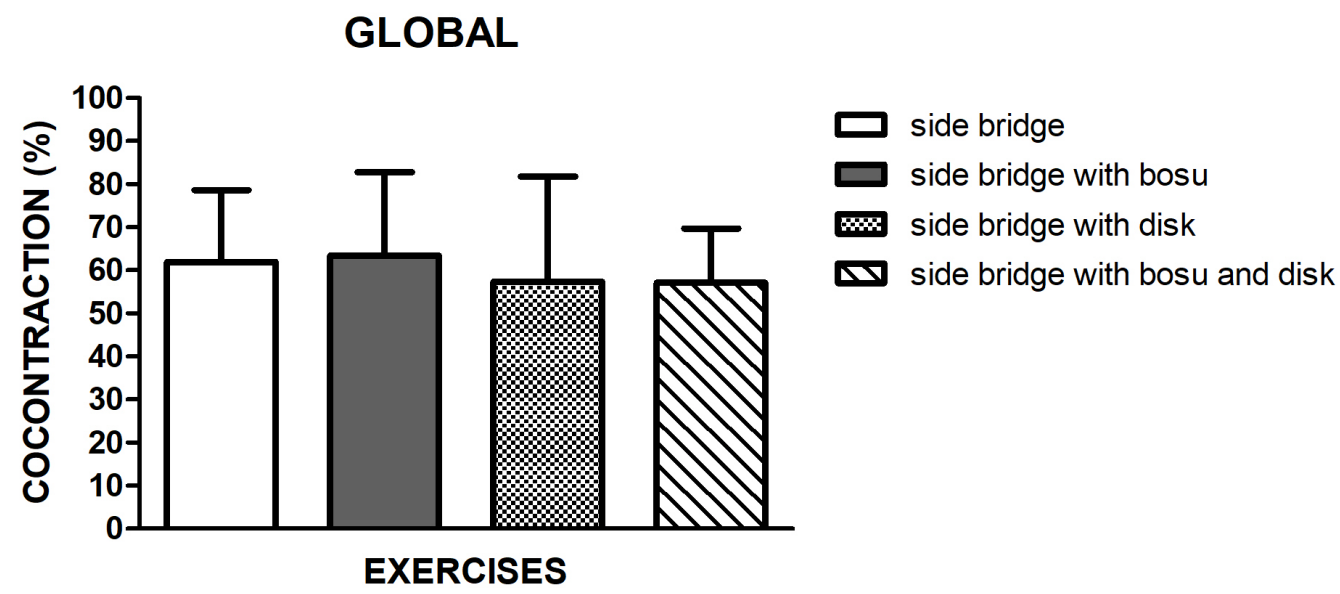

Figure 2. Global co-contraction of the trunk muscles during side bridge exercises. The bars represent the mean and standard deviation. 


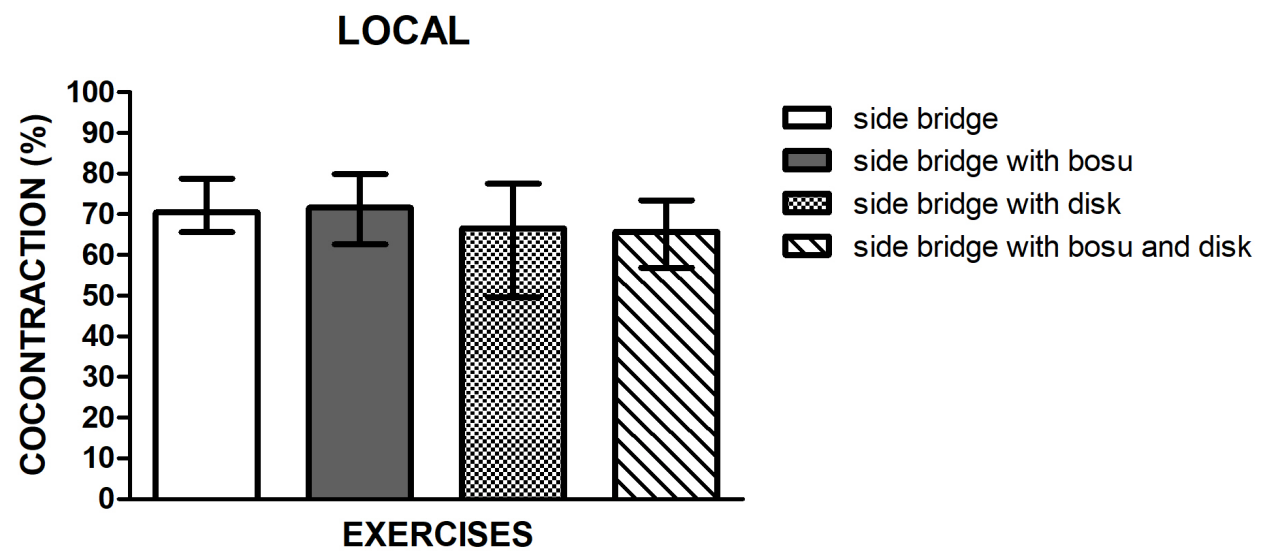

Figure 3. Local co-contraction of the trunk muscles during side bridge exercises. The bars represent the median, first and third quartiles.

\section{DISCUSSION}

In the present study, no significant differences were observed in the rates of cocontraction of the flexor and extensor muscles of the trunk comparing normal stabilization exercises with single and double instability. The rationale for using the unstable surface in trunk stabilization exercises is based on the potential for increase trunk disturbance and displacement of the center of gravity, requiring higher neuromuscular demand to maintain adequate spinal control during exercise (DESAI; MARSHALL, 2010).

However, this higher neuromuscular demand seems to be restricted to the changes in the recruitment of core specific muscles, without influencing the cocontraction rates. Imai et al. (2010) demonstrated higher recruitment of the RA muscle in the side bridge exercise with double instability (disk and bosu) compared to normal stability. Czaprowski et al. (2014) demonstrated greater activity of the RA and EO muscles in the side bridge with bosu in comparison to the soil, however, both authors did not evaluate the cocontraction, which makes it a limiting factor and open to further questioning.

Therefore, the use of an unstable surface in the stabilization exercises mainly increases the electromyographic signal of the global abdominal muscles, with no concomitant increase in the recruitment of ES and MF antagonist muscles and local abdominal muscles, situation that may become an undesirable factor in the initial phase of core training, beyond the muscular endurance, the stabilization exercises must emphasize, in first stage, the selective activation of the stabilizer local muscles (MF, IO and TA) (NEUMANN, 2011).
Therefore, it was not confirmed the hypothesis that the use of unstable surface produces a higher co-contraction. This suggests that the cocontraction pattern on the side bridge with and without instability is similar, however, it should be noted that in the present work an electromyographic evaluation of the trunk muscles in the side bridge was performed using five seconds of isometric contraction, which may explain the absence of significant differences.

Most of the studies evaluated the electromyographic activity using five (BAK et al., 2017; CALATAYUD et al., 2017; LEE; KIM; KIM, 2016 ; BYRNE et al., 2014; CZAPROWSKI et al., 2014; SOUSA et al. 2014; VERA-GARCIA; BARBADO; MOYA, 2014; FELDWIESER; SHEERAN; ESTEBAN, 2012; GARCÍAVAQUERO et al., 2012; KANG; JUNG; YU, 2012; IMAI et al., 2010; VERA-GARCIA et al., 2010) or ten seconds (KIM; OH; PARK; 2013; MAEO et al., 2013; TAN et al., 2013) of contraction in the trunk stabilization exercises, a situation that aided in the elaboration of the experimental design of the present research.

However, Faries and Greenwood (2007) stated that stabilization exercises require little or no movement of the spine and typically require durations of 30-45 seconds using assumptions in the type I fiber composition of the local stabilizers. In this way, the limited time used in the present research may have suppressed the desirable effect of the unstable surface to increase trunk disturbance and instability, since, according to Behm and Colado (2012), the use of unstable resistance training produces greater co-contraction and increase of the antagonistic activity causes greater joint stiffness and better stability. 
Future studies should analyze co-contraction in trunk stabilization exercises with and without different unstable surfaces using a longer execution time (30 to 45 seconds), in order to facilitate the practical application of their results.

The co-contraction of the MF and IO muscles is fundamental to improve the stability of the lumbar spine, since, the first muscle is important to increase the stability of the lumbar vertebrae and sacroiliac joint, while the second increases intraabdominal pressure and tension in the aponeurosis thoracolumbar, improving segmental stabilization of the trunk (MARQUES et al., 2012).

It is important to emphasize that in the present study the analysis of the co-contraction was not restricted to the local muscles, because it is believed that the stability of the spine is not performed only by a single group of muscles of the trunk, it depends on the joint action of all muscles of this region. Therefore, it is imperative that future studies analyze the level of global and local cocontraction of the trunk muscles so that a better understanding of the active system can be obtained during different stabilization exercises.

Once the electromyographic signal has been acquired, there are many processing methods that can be used to interpret the data (MARCHETTI; DUARTE, 2006). Several studies have analyzed the electromyographic activity of the core muscles in different isometric trunk stabilization exercises (GARCÍA-VAQUERO et al., 2012; GOTTSCHALL et al., 2013, MAEO et al., 2013) with and without unstable surfaces (KANG et al., 2012; CZAPROWSKI et al., 2014; SNARR; ESCO, 2014). However, most of these studies have considered the intensity of the antagonist activation as a measure of co-contraction. However, it is known that the intensity of the antagonistic activity does not always correspond to the co-contraction, since this is a phenomenon defined as the simultaneous activation of two or more muscles around the joint, becoming a limiting factor of these works.

A limitation of this work was the absence of data register about cinemetry, which may have caused variations in the posture of the spine during the exercises. Besides that, the present research used a group of male volunteers, relatively young, healthy, physically active and no history of low back pain, therefore, the results must be applicated with precaution for different populations. Although the volunteers had experience in resistance training and in the side bridge in the ground besides had performed a familiarization session, it must be emphasized that the lack of proper training time in the side bridge exercise with the different unstable surfaces, can be considered as another limitation, a situation that can impact on the muscular response pattern due to the absence of specific motor coordination for the exercises performed. Another limitation of this study, was the absence of the measurement of body fat percentage.

\section{CONCLUSION}

The use of unstable surface in the side bridge stabilization exercise does not increase the level of co-contraction of the trunk flexor and extensor muscles compared to normal stability. However, future studies should use a longer time of isometric contraction in trunk stabilization exercises to optimize the understanding of the effects of different unstable equipment on global and local levels of co-contraction of the trunk muscles. 
RESUMO: A cocontração muscular é um fenômeno caracterizado pela contração simultânea de dois ou mais músculos em torno de uma articulação. Objetivou-se comparar a cocontração antagonista da musculatura local e global do tronco durante o exercício prancha lateral, em quatro situações: (a) estável; (b) instabilidade no membro superior com bosu; (c) instabilidade no membro superior com disco e (d) instabilidade dupla. A amostra foi composta por 20 voluntários do gênero masculino e a coleta de dados foi realizada com eletrodos de superfície diferenciais simples. A atividade eletromiográfica foi coletada dos músculos Reto do Abdome (RA), Oblíquo Interno do Abdome (OI), Multifido (MU) e Eretor da Espinha (EE). Foram utilizadas rotinas específicas desenvolvidas no programa Matlab (Mathworks Natick, EUA) para calcular a porcentagem de cocontração antagonista entre os músculos locais (OI / MU) e globais (RA / ES). Os dados obtidos foram submetidos à análise estatística paramétrica (ANOVA medidas repetidas) ou não paramétrica (Friedman). Os resultados demonstraram que não foram observadas diferenças significativas no padrão de cocontração global e local nos distintos exercícios de prancha lateral com e sem superfície instável. Conclui-se que a utilização de superfície instável no exercício de estabilização de prancha lateral não aumenta o nível de cocontração dos músculos flexores e extensores do tronco em comparação a estabilidade normal. Todavia, futuros estudos devem utilizar um tempo maior de contração isométrica nos exercícios de estabilização do tronco para otimizar a compreensão dos efeitos dos diferentes equipamentos instáveis sobre os níveis de cocontração global e local dos músculos do tronco.

PALAVRAS-CHAVES: Eletromiografia. Core. Bosu. Disco de equilíbrio.

\section{REFERENCES}

ATKINS, S. J.; BENTLEY, I.; BROOKS, D.; BURROWS, M. P.; HURST, H. T.; SINCLAIR, J. K. ElectromyographicResponse of Global Abdominal Stabilizers in Response to Stable- and Unstable-Base Isometric Exercise.Journal Of Strength And Conditioning Research, v. 29, n. 6, p.1609-1615, 2015. https://doi.org/10.1519/JSC.0000000000000795

BAK, J; SHIM, S.; CHO, M.; CHUNG, Y.The Effect of Plank Exercises with Hip Abduction Using Sling on Trunk Muscle Activation in Healthy Adults.Journal of Korean Physical Therapy, v.29, n.3, p.128-134, 2017. https://doi.org/10.18857/jkpt.2017.29.3.128

CALATAYUd, J.; CASAÑA,J.; MARTÍN, F.; JAKOBSEN, M. D.; COLADO, J.C.; ANDERSEN, L. L. Progression of Core Stability Exercises Based on the Extent of Muscle Activity. American Journal of Physical Medicine \& Rehabilitation, v.96, n.10, p.694-699, 2017. https://doi.org/10.1097/PHM.0000000000000713

BEHM, D. G.; DRINKWATER, E. J.; WILLARDSON, J. M.; COWLEY, P. M.The use of instability to train the core musculature. Applied Physiology, Nutrition, and Metabolism, v .35, p. 91-108, 2010.

BEHM, D.; COLADO, J. C. The effectiveness of resistance training using unstable surfaces and devices for rehabilitation.The International Journal of Sports Physical Therapy, v. 7, n. 2, p. 226-241, 2012.

BYRNE, J. M.; BISHOP, N S.; CAINES, A. M.; CRANE, K. A.; FEAVER, A. M.; PEARCEY, G. E. P. Effect of using a suspension training system on muscle activation during the performance of a front plank exercise.

Journal of Strength and Conditioning Research, v.28, n.11, p.3049-3055, 2014. https://doi.org/10.1519/JSC.0000000000000510

CZAPROWSKI, D.; AFELTOWICZ, A.; GEBICKA, A.; PAWLOWSKA, P.; KEDRA, A.; BARRIOS, C.; HADAŁA, M. Abdominal muscle EMG activity during bridge exercises on stable and unstable surfaces. Physical Therapy in Sport, v.15, n.3, p.162-168, 2014. https://doi.org/10.1016/j.ptsp.2013.09.003

DE LUCA, C. J. The use of surface electromyography in biomechanics.Journal of Applied Biomechanics, v. 13, n. 2, p. 135-163, 1997. https://doi.org/10.1123/jab.13.2.135 
DESAI, I.; MARSHALL, P. W. M. Acute effect of labile surfaces during core stability exercises in people with and without low back pain. Journal of Electromyography and Kinesiology, v. 20, n.6, p. 1155-1162, 2010. https://doi.org/10.1016/j.jelekin.2010.08.003

ELLSWORTH, A. Treinamento do core: Anatomia ilustrada - guia completo para o fortalecimento do core. Barueri: Manole, 2012.

EKSTROM, R. A.; DONATELLI, R. A.; CARP, K. C. Electromyographic analysis of core trunk, hip and thigh muscles during 9 rehabilitation exercises. Journal of Orthopaedic and Sports Physical Therapy, v. 37, n. 12, p.754-762, 2007.

https://doi.org/10.2519/jospt.2007.2471

FARIES M. D.; GREENWOOD M. Core Training: Stabilizing the Confusion. Strength and Conditioning Journal, v. 29, n. 2, p. 10-25, 2007. https://doi.org/10.1519/00126548-200704000-00001 https://doi.org/10.1519/1533-4295(2007)29[10:CTSTC]2.0.CO;2

FELDWIESER, F. M.; SHEERAN, L.; MEANA-ESTEBAN, A.; SPARKES, V. Electromyographic analysis of trunk-muscle activity during stable, unstable and unilateral bridging exercises in healthy individuals. European Spine Journal, v. 21, n. 2, p. 171-186, 2012. https://doi.org/10.1007/s00586-012-2254-7

GARCÍA-VAQUERO; M.P.; MORESIDE, J. M.; BRONTONS-GIL, E. PECO-GONZÁLEZ, N. VERAGARCIA, F. J. Trunk muscle activation during stabilization exercises with single and double leg support. Journal of electromyography and kinesiology.v. 22, n.3, p. 398-406, 2012.

https://doi.org/10.1016/j.jelekin.2012.02.017

GOTTSCHALL, J. S.; MILLS, J.; HASTINGS, B. Integration core exercises elicit greater muscle activation than isolation exercises. Journal of Strength and Conditioning Research, v. 27, n. 3, p. 590-6, 2013. https://doi.org/10.1519/JSC.0b013e31825c2cc7

HERMENS, H. J.; FRERIKS, B.The SENIAM cd-rom: European recommendations for surface electromyography. Netherlands: Roessingh Research and Development, 1999. 1 CD.

HIBBS, A. E.; THOMPSON, K. G; FRENCH, D. N.; HODGSON, D.; SPEARS, I. R. Peak and average rectified EMG measures: Which method of data reduction should be used for assessing core training exercises? Journal of Electromyography and Kinesiology, v. 21, n.1, p. 102-111, 2011.

https://doi.org/10.1016/j.jelekin.2010.06.001

IMAI, A.; KANEOKA, K.; OKUBO, Y.; SHIINA, I.; TATSUMURA, M.; IZUMI, S.; SHIRAKI, H. Trunk Muscle Activity During Lumbar Stabilization Exercises on Both a Stable and Unstable Surface. Journal of Orthopaedic and Sports Physical Therapy, v.40, n.6, 369-375, 2010. https://doi.org/10.2519/jospt.2010.3211

KANG, H.; JUNG, J.; YU, J. Comparison of trunk muscle activity during bridging exercises using a sling in patients with low back pain. Journal of Sports Science and Medicine, v. 11, n.3, p. 510-515, 2012.

KIM, M. J.; OH, D. W.; PARK H. J. Integrating arm movement into bridge exercise: Effect on EMG activity of selected trunk muscles. Journal of Electromyography and Kinesiology, v. 23, n.5, p.1119-1123, 2013. https://doi.org/10.1016/j.jelekin.2013.07.001

KONRAD, P. The ABC of EMG: A Practical Introduction to Kinesiological Electromyography. Noraxon INC. USA., 2005.

LEE, J.S.; KIM, D. Y.; KIM, T.H.The comparison of abdominal muscle activation on unstable surface according to the different trunk stability exercises. The Journal of Physical Therapy Science, v.28, n.3. p.1003-1006, 2016. https://doi.org/10.1589/jpts.28.1003 
MAEO, S.; TAKAHASHI, T.; TAKAI, Y.; KANEHISA, H. Trunk Muscle Activities during Abdominal Bracing: Comparison among Muscles and Exercises. Journal of Sports Science and Medicine, v.12, n.3, p.467-474, 2013.

MARCHETTI, P. H.; DUARTE, M. Instrumentação em eletromiografia. Laboratório de Biofísica; 129.[acesso 2017 Ago 11]. 2006. Disponível em: http://lob.iv.fapesp.br.

MARCHETTI, P. H.; SCHOENFELD, B. J.; SILVA, J. J.; GUISELINI, M. A.; FREITAS, F. S.; PECORARO, S. L.; GOMES, W. A.; LOPES, C. R. Muscle Activation Pattern During Isometric Ab Wheel Rollout Exercise in Different Shoulder Angle-Positions. Medical Express, v. 2, n. 4, p. 1-5, 2015.

https://doi.org/10.5935/MedicalExpress.2015.04.04

MARQUES, N. R.; HALLAL, C. Z.; GONÇALVES, M. Padrão de co-ativação dos músculos do tronco durante exercícios com haste oscilatória. Motriz, v.18, n.2, p.245-25, 2012. https://doi.org/10.1590/S198065742012000200004

MARQUES, N. R.; MORCELLI, M. H.; HALLAL, C. Z.; GONÇALVES, M. EMG activity of trunk stabilizer muscles during Centering Principle of Pilates Method. Journal of Bodywork and Movement Therapies, v.17, n.2, p.185-191, 2013. https://doi.org/10.1016/j.jbmt.2012.06.002

MORITA, A. K.; MARQUES, N. R.; NAVEGA, M. T. Neuromuscular control strategies of the trunk antagonist muscles during the Biering-Sorensen test in individuals with recurrent low back pain and healthy subjects. Motriz, v. 22, n.4, p. 266-271,2016. https://doi.org/10.1590/s1980-6574201600040008

NEUMANN, D. A. Cinesiologia do Aparelho Musculoesquelético: Fundamentos para Reabilitação. 2. ed. Rio de Janeiro: Elsevier, 2011.

OLIVER, G. D.; STONE, A. J.; PLUMMER, H. Electromyographic Examination of Selected Muscle Activation During Isometric Core Exercises. Clinical Journal of Sport Medicine, v. 20, n. 6, p. 452-457, 2010. https://doi.org/10.1097/JSM.0b013e3181f7b0ef

ROSSI, D. M.; MORCELLI, M. H.;MARQUES, N. R.;HALLAL, C. Z.;GONÇALVES, M.; LAROCHE, D. P.; NAVEGA, M. T. Antagonist cocontraction of trunk stabilizer muscles during Pilates exercises. Journal of Bodywork and Movement Therapies, v. 18, n. 1, p. 34-41, 2014. https://doi.org/10.1016/j.jbmt.2013.04.006

SNARR, R. L.; ESCO, M. R. Electromyographical Comparison of Plank Variations Performed With and Without Instability Devices. Journal of Strength and Conditioning Research, v. 28, n. 11, p.3298-3305, 2014. https://doi.org/10.1519/JSC.0000000000000521

SNARR, R. L.; HALLMARK, A. V.; NICKERSON, B. S.; ESCO, M. R. Electromyographical Comparison of Pike Variations Performed With and Without Instability Devices. Journal of Strength and Conditioning Research, v. 30, n. 12, p.3436-3442, 2016. https://doi.org/10.1519/JSC.0000000000001436

SOUSA, G.C.; LIZARDO, F.B.; BERNARDINO JÚNIOR, R.; SILVA, D.C.O.; GREGÓRIO, F.C., SANTOS, L.A.; BÉRZIN F.; BIGATON, D.R. Análise eletromiográfica dos músculos do Core em exercícios de estabilização do tronco com diferentes superfícies instáveis. Revista Brasileira de Ciências da Saúde Suplemento. p.35-40, 2014.

SUNDSTRUP, E.; JAKOBSEN, M. D.; ANDERSEN, C. H.; JAY, K.; ANDERSEN, L. L. Swiss ball abdominal crunch with added elastic resistance is an effective alternative to training machines. International JournalofSports Physical Therapy, v.7, n. 4, p. 372-380, 2012. 
TAN , S.; CAO, L.; SCHOENFISCH, W.; WANG, J. Investigation of Core Muscle Function through Electromyography Activities in Healthy Young Men. Journal of Exercise Physiology-online, v. 16, n. 1, p. 45-52, 2013.

VERA-GARCIA, F. J.; MORESIDE, J. M.; MCGILL, S. M. MVC techniques to normalize trunk muscle EMG in healthy women.Journal of Electromyography and Kinesiology,v. 20, n. 1; p. 10-6, 2010. https://doi.org/10.1016/j.jelekin.2009.03.010

VERA-GARCIA, FRANCISCO J; BARBADO, DAVID; MOYA, Manuel. Trunk stabilization exercises for healthy individuals. Brazilian Journal of Kinanthropometry and Human Performance, v. 16, n. 2, p. 200$211,2014$.

WINTER, D. A. Biomechanics and motor control of human movement. New York: Wiley, 2005. 